\title{
Robotic allied with the STEAM Methodology as a proposal to solve the challenges of Professional Education during the Covid-19 pandemic
}

\author{
Jean Mendes Nascimento \\ Centro Estadual de Educação \\ Tecnológica Paula Souza \\ São Paulo, Brasil \\ jeean.mendes@hotmail.com
}

\begin{abstract}
The educational environment undergoes constant changes and the teaching methodologies must be updated according to their contexts and in their due times of performance, outdated methodologies end up not being effective if applied in new generations. In the face of the world pandemic scenario presented in 2020 , a model of remote classes was adopted following rules of social distance. This article seeks to present an alternative for the formation of students' skills in a technical school in the city of São Paulo. For this, the STEAM methodology is used to develop projects on an online platform based on real simulations of the daily life of the area. At the end, a positive result is presented for the methods approached according to the evaluation of the students participating in the project.
\end{abstract}

Keywords - STEAM methodology, covid-19, active methodologies.

\section{INTRODUCTION}

The classroom is an environment in constantly changing. In practical terms, a class given at a certain time will never be the same class at any other time. As much as the same methodology is used, individuals are unique and their personal experiences and emotions brought about change the teaching-learning environment in a unique way. This transformation is usually intensified with the constant renewal of the student age group. Therefore, pedagogical practices that can be considered "outdated", for example, do not encourage students already contextualized in the information age.

They called STEAM methodology is an interdisciplinary in nature, being considered an agile methodology, it brings integration between concepts of science, technology, engineering, arts and mathematics. An effective way to apply this concept through the development of projects in the teaching-learning process.

To all these concepts become into reality is not simple. It is an interdisciplinary integration process that it is also necessary to apply project management concepts. However, the year 2020 totally transformed the scenario we had known as a classroom, separating teachers and students during the Covid-19 pandemic that affected the whole world, making even more complex the teaching-learning process and obtaining practical skills provided in the course plan necessary for the formation of students.
The current work tries to present an alternative integrating agile methodologies, such as, for example, the STEAM methodology and project management so that the students of a State Technical School located in the city of São Paulo can develop the necessary practical skills and provided it for the curriculum in a technical course belonging to the technological axis "Control and Industrial Processes" during remote education imposed by the pandemic.

The practical proposal provides the use of an open source platform which is available on the Internet. On it, the students can develop small projects guided by the teacher using sensors and actuators based on the programming of an Arduino. Each of the projects developed are different nature, but with each application made, the student acquires the necessary technical competence to be able to develop a final project.

In the final project, the student must integrate all the knowledge acquired for the mounting of a robotic manipulator or a mobile robot on the online platform. This time, in addition to the resources already used, the student must design and model the structure of the project in $3 \mathrm{D}$, also using resources from the same application in question.

It is expected that, in addition to achieving the skills and competencies provided for in the curriculum, the project that integrates the interdisciplinary of the STEAM methodology and the concepts of project management will make the classes more dynamic, attractive and interesting for the student even when facing all the distance. Such expectations can be noticed through the teacher-student interaction during the application of the teaching-learning process and confirmed quantitatively through a questionnaire applied to the participants after the end of the project.

\section{STEAM METHODOLOGY}

Modern society faces new paradigms when it comes to applying knowledge effectively, which has led many authors and theorists to highlight the problems of an educational system based, fundamentally, on the historical separation between humanities and sciences [1].

This new society, called globalized, allows massive access of the population to information through the digital media that are increasingly in present day, it is necessary to rethink the methodologies used daily, in order to add greater value to knowledge, make the daily life of more dynamic 
classroom, in addition to breaking the traditional teacherstudent relationship, since, today, the speed of knowledge construction favors these two characters.

Active learning occurs effectively when the student interacts with the subject under study, listening, asking, discussing, doing and teaching, becoming able to produce knowledge instead of receiving it passively [2].

The STEAM methodology, presented as an active methodology, is an innovative trend that aims to change the status quo of current education. It seeks to allow the student, autonomously and creatively, to explore their curiosity and develop meaningful learning [3].

The idea emerged named STEM methodology, addressing the same areas of knowledge with the exception of the Arts. In its first version, STEM, it was another teaching-learning method that contributed to the historical opposition between exact sciences and humanities. The STEAM methodology recognizes the importance of Arts and Designs, giving due importance to creative and reflective practices in science and technology teaching [4].

The idea behind STEAM in education is to break barriers between disciplines. This is interdisciplinarity par excellence [3]. The integration of sciences, technologies and arts opens new doors for designs of curricular connections previously considered incompatible and establishes a whole set of new possibilities for relationships between competences and themes present in school curriculum [1].

\section{DIVERSIFIED METHODOLOGIES IN PROFESSIONAL EDUCATION}

World Bank reports show that Brazil has made progress in technical and professional education, especially in expanding access to this type of education and improving the quality of that education. This can be attested to the country's victory in WorldSkills, for example, internationally recognized technical and professional competition [5]. The federal network of technical and professional education has grown exponentially in the country, expanding access to this type of education by $114 \%$ in the country between 2002 and 2010 [6]

Professional and technical education is a teaching system framed at the middle level of the Brazilian educational system. In Brazil, 1,914,749 students enrolled in professional education courses across the country. Most students enrolled in public or private vocational education networks are up to 30 years old, being $78.8 \%$ of the total amount. The number of women is predominant in practically all age groups, being female $56.7 \%$ of the total number of enrollments [7].

Diversified teaching methodologies are becoming common in the current scenario. However, the vast majority of pedagogical practices end up being applied in the disciplines of the Common National Curricular Base. The duality between basic education and professional education is historical in Brazil, since the teaching of sciences, letters and humanities was intended only for the elite that wanted to enter higher education, while the less favored, at most, could attend professional education and learn an industrial or agricultural work [8].

A professional education focused on the formation of skills, requires a curricular organization that takes into account the diversity of educational processes inside and outside the school and the interests and priorities of the individual. Therefore, meaningful learning, contextualized teaching and skills training are also necessary in professional education. In this scenario, the author applies what he calls the Project Method systematics, in classes of an Electronic Technician course in the state of Minas Gerais. The Project Method is a teaching-learning strategy that aims, through the investigation of a theme or problem, to link theory and practice, generating diversified and real-time learning in a pedagogical context where the student is an agent of knowledge production [9].

Another article presents the use of project design through scientific experimentation as an active learning methodology for teaching Ecology to students on a Technical Course in the Environment in the state of Pernambuco. According to the author, active learning through scientific experimentation and project design facilitates the construction of connections between newly acquired abstract information and the real world. The investigations produced in the classroom and applied in the field help to expand previously introduced information and help to consolidate new knowledge [10].

In his work, a new author brings an applied investigation in a workshop on the perception of a group of professors from a Technical Course in Administration in the state of Rio Grande do Sul in relation to active methodologies. The author applies an open questionnaire and, according to some content analysis methods, concludes that the teachers analyzed have often used or use active methodologies in their classes, but are unaware of this nomenclature. And yet, they felt motivated to use strategies guided by active methods that they did not yet know and to participate in training opportunities in this line [11].

Another study presents the development of business games and "gamification" as an alternative to the gaps and limitations existing both in the course plans, as well as in the resources and structures available in courses on the technological axis of Management and Business at a technical school in the state of São Paulo. In this work, in addition to applying games as a simulation in order to intensify student training, games are developed by students themselves in the form of teamwork and applied to other students of different grades. At the end, it is concluded quantitatively through a questionnaire. The satisfaction of the participating students regarding the new practice capable of fixing theoretical contents and developing their behavioral skills [12].

\section{METHODS}

In view of the pandemic scenario presented during the 2020 academic year, remote online classes emerged as an option to continue studying while social distancing was applied in an attempt to preserve the physical integrity of students and teachers. In view of the above, alternatives were designed so that the same teaching-learning process could reach students equally efficiently in this new teaching perspective.

One of the main challenges in this scenario was to achieve the necessary skills from practical laboratory applications. Specifically, in disciplines in the Control and Automation area, knowledge about Arduino and its applications with sensors and actuators is increased. The implementation of this content to the disciplines seeks to solve gaps required by the course plan in practical activities 
that unfortunately are impossible due to the lack of high cost resources in the school.

In order for this same content to reach the students, a "self-training" was carried out by the teacher on the TinkerCad platform, which is maintained by AutoDesk in an open-source manner, that is, the resources are made available free of charge and any changes made to a project are not injures manufacturers' rights or licenses. One of the main factors that led to the choice of this application is the fact that it is an online platform, not requiring a specific software or application to access, just an Internet browser. Therefore, it is a platform that enables the democratization of this specific teaching-learning process, as it allows access for all students, whether by a computer or a mobile device.

\section{A. Methodology Applied to Projects}

In view of the pandemic scenario presented during the 2020 academic year, remote online classes emerged as an option to continue studying while social distancing was applied in an attempt to preserve the physical integrity of students and teachers. In view of the above, alternatives were designed so that the same teaching-learning process could reach students equally efficiently in this new teaching perspective.

The applied methodology starts from the presentation of the tool to the students by the teacher. After previous lectures necessary as an introduction to the theme, assemblies and programming of low complexity systems were created, first by the teacher, then by the students.

The teacher carried out the entire assembly of a small project simulating a real situation in class, later, based on the exemplified assembly, the students performed a different activity, but always based on the assembly presented. For example, the first practical application was the assembly and programming of a traffic light by the teacher. Later, in addition to reproducing and associating the project, the students had the task of assembling a traffic light at a crossing of roads, that is, the integration of two traffic lights.

In another example, the teacher applied a simple assembly and programming, where, when a button is pressed, an LED lights up and when the button is not pressed, the LED remains off, in this way, students acquire the ability to manipulate input signals in the microcontroller. Therefore, students were asked to set up a traffic light project for cars and pedestrians whose logic of operation implies a traffic light always allowing the passage of cars, however, when a pedestrian crossing through a button is required, the traffic light should change, stop the traffic of cars and release the pedestrian crossing, after counting a certain period of time programmed, the system returned to its initial logic, allowing the traffic of cars and blocking the crossing of pedestrians. In this way, two logics of simple existing projects resulted in a new project at a more advanced level.

It was also up to the students to produce and deliver a report on the assembly and programming, where it was necessary to include a photo of the assembly on the platform and the programming with explanatory commentary on the line-by-line programming logic of the program.

The students also developed other projects and applications on the platform in order to acquire content from some specific programs. Among them, approaches with analog inputs were developed using temperature sensor and light sensor and digital inputs using buttons and infrared sensor. The use of these input signals was always integrated with the actuation of actuators in the output signals. Among the actuator options, the use of LEDs, buzzer and motors and servo motors was largely applied to the projects. Altogether, until the challenge of the final project, eight applications were made, always simulating automation and control of situations in real projects.

\section{B. Final Project}

The final project is the integrator that uses the entire knowledge base acquired during previous projects with the arts and design. In the final project, students, in pairs, could choose to carry out the development of the complete project of a mobile robot, car type, bluetooth controller through a cell phone application or a robotic manipulator, arm type, also with commands received by a mobile app.

In this application, students should, in addition to making use of sensors and actuators for the full functioning of the project, perform all the stages of 3D modeling of the project structure of their choice, also on the TinkerCad platform, with artistic creativity being one of the criteria of evaluation of the pairs.

The outcome of the entire methodology took place with an online presentation of the projects. Each pair organized and carried out the transmission of the screen presenting the project and explaining each stage of construction and operation. Specifically, it was necessary to explain about the 3D model, the electrical circuit and the programming responsible for the operation of the entire project, always justifying their choices throughout its development.

\section{RESULTS AND DISCUSSION}

The results were presented by the students weekly as the development of each specific project was carried out. Examples of circuit assemblies made by students on the platform can be seen in Figure 1.

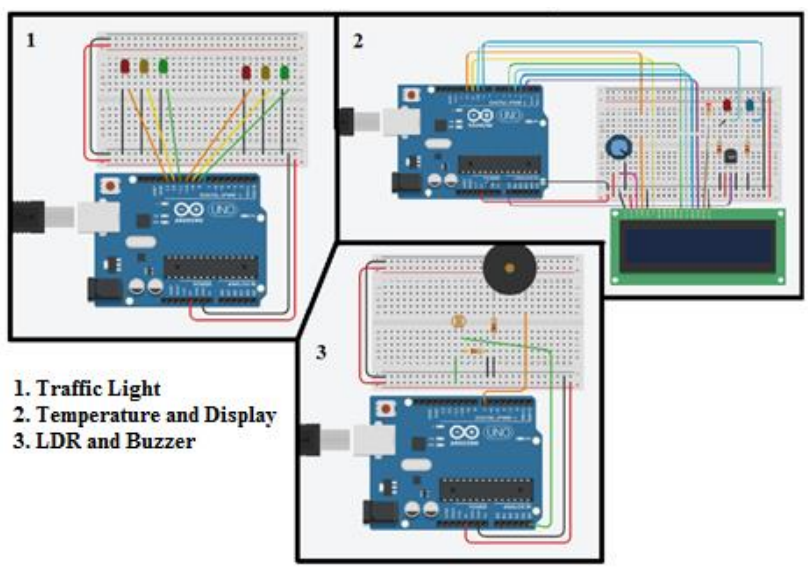

Fig. 1. Example of assembling circuits made by students.

It was possible to observe during the management of the methodology and the application of each project in class, that the students were more interested and participative, demonstrating a better interaction within the online classroom environment.

When the final project was applied, the same feedback was obtained from the students, this time, even a little more enthusiastically for presenting the development of something 
completely new. In Figure 2, some models developed by the students in the final step of the STEAM methodology are presented.

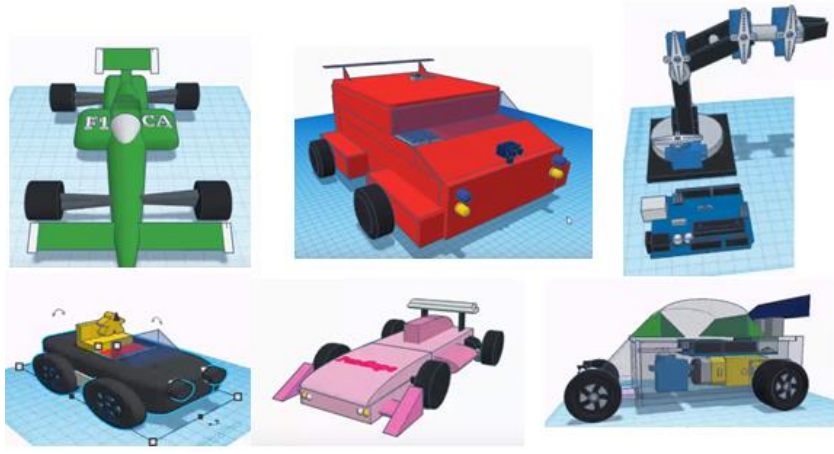

Fig. 2. Examples of final project developed by the students

In addition to the perception of direct contact in the teacher-student relationship in the online learning environment, a survey research was applied to students, with the intention of obtaining feedback about the methodology worked.

The students were asked to evaluate the methodology used and the results presented through a questionnaire where it was not necessary to identify themselves. There were 32 respondents with an average age of 29 years, five of whom were female and the rest male.

Among the series of questions asked to students, some approaches should be highlighted. The students' opinion was asked in relation to the methodology used considering the pandemic scenario, the question applied was "In your opinion and considering online education in the current pandemic scenario, do you consider the methodology used to be adequate for the realization of practical activities?". In this question, $100 \%$ of respondents answered "YES", that is, they consider the methodology appropriate for the current moment. In another question, respondents needed to evaluate the applied methodology by assigning mentions $\mathrm{F}$ for Fail, $\mathrm{R}$ for regular, $\mathrm{G}$ for good and VG for very good. The result of this question is shown in Figure 3, where the vast majority of respondents attributed a positive result, with $12(38 \%)$ considering the methodology good and $20(62 \%)$ considering it as very good.

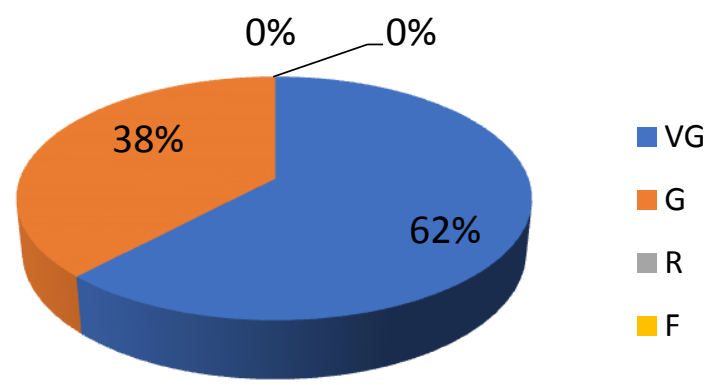

Fig. 3. Evaluation of students about the applied methodology

The students were also able to answer particularly about the teacher, evaluating the methods of approach in teaching, commitment, assistance in doubts, etc., and the feedback obtained in questions of this type were also positive.

\section{CONCLUSION}

This article sought to present an alternative so that students could achieve the skills required by practical activities in the curriculum of their technical course through the use of STEAM methodology and project management with robotic even in the remote education imposed by the Covid-19 pandemic in the year of 2020. According to the teaching perception during the applied methodology and the results obtained quantitatively with the questionnaire answered by the students, it can be concluded that the methodology brings good results, being, in general, the positive final result.

Allied to the positive result evaluated at the end of the methods used, it was also noticeable the improvement in the interaction of students in the online classroom environment, improving the dynamics of the classes, making them more gainful and pleasurable for both, students and the teacher.

The platform used in this application must be used again even with the return of the presential classes, but this time, combined with the use of physical equipment. The aim is to provide yet another alternative for students, such as training at home in the absence of equipment and testing with simulation before real laboratory applications.

\section{ACKNOWLEDGMENT}

I thank my dear students for providing that this experience was possible

\section{REFERENCES}

[1] ZUBIAGA, A.; CILlERUELO, L. Una aproximación a la educación STEAM - Práticas Educativas em la Encrucijada Arte, Ciencia y Tecnología. In: Investigar en psicodidáctica: una realidad en auge. Univerdidad del País Vasco, Bilbao, 2014.

[2] SEgurA, E., KALHIL, J. B. A metodologia ativa como proposta para o ensino de ciências. Revista REAMEC, Cuiabá, 2015.

[3] SILVA, I. O.; ROSA, J. E. B.; HARDOIM, E. L.; NETO, G. G. Educação Científica empregando o método STEAM e um makerspace a partir de uma aula-passeio. In: Latin American Journal of Science Education. Cidade do México, 2017.

[4] LORENZIN, M. P.; BIZERRA, A. F. Compreendendo as concepções de professores sobre o STEAM e as suas transformações na construção de um currículo globatizador para o ensino médio. Revista da SBEnBio, Maringá, 2016.

[5] COSTIN, C. Ensino Técnico e Profissional no Brasil. Estadão, Opinião., São Paulo, 2015. Disponível em: $<$ http://opiniao.estadao.com.br/noticias/geral,ensinotecnico-e-profissional-no-brasil,10000003243>. Acesso em 13 set. 2020.

[6] CARdoso, C. O Desafio do Ensino Técnico. Carta Capital, Educação. São Paulo, 2012. 
Disponível

em: <https://www.cartacapital.com.br/educacao/odesafio-do-ensino-tecnico>. Acesso em 02 jul. 2017.

[7] INEP, Instituto Nacional de Estudos e Pesquisas Educacionais Anísio Teixeira. Censo da Educação Básica 2019. MEC, Ministério da Educação, 2019. Disponível em: <http://portal.inep.gov.br/informacao-da-publicacao//asset_publisher/6JYIsGMAMkW1/document/id/679 8882> Acesso em: 04 de set. 2020.

[8] MOURA, D. H. Educação básica e educação profissional e tecnológica: Dualidade histórica e perspectiva de integração. HOLOS, vol. 2, p. 4-30. Natal, 2007.

[9] BARBOSA, E. F.; GONTIJO, A. de F.; SANTOS F. F. dos. Inovações pedagógicas em educação profissional: uma experiência de utilização do método de projetos na formação de competências. Educ. Tecnol., v. 8, n. 2, p. 06-13. Belo Horizonte, 2003.

[10] DANTAS, F. C. C.; TORRES, R. M. A elaboração de projetos como metodologia de aprendizagem ativa para o ensino de ecologia na educação profissional técnica. Revista Brasileira de Meio Ambiente, v. 8, n. 4, p. 02-13. Recife, 2020.
[11] DIESEL, A.; MARCHESAN, M. R.; MARTINS, S. N. Metodologias ativas de ensino na sala de aula: um olhar de docentes da educação profissional técnica de nível médio. Revista Signos, ano 37, n. 1, p. 153-169. Lajeado, 2016

[12] NASCIMENTO, J. M.; SENA, G. S. Desenvolvimento de jogos empresariais: $O$ aluno como protagonista através de metodologias ativas. In VI Simpósio dos Ensinos Médio, Técnico e Tecnológico: Desafios dos Ensinos Médio, Técnico e Tecnológico: Ações Formativas no Contexto Contemporâneo. São Paulo: CPS, 2019. 